\title{
Rancang Bangun Viskosimeter Fluida Metode Bola Jatuh Bebas Berbasis Mikrokontroler ATMEGA16
}

\author{
Didik Aryanto, ${ }^{*}$ Ernawati Saptaningrum, dan Wijayanto \\ Jurusan Pendidikan Fisika, FPMIPA, IKIP-PGRI Semarang \\ Jl. Dr. Cipto Mangunkusumo, Semarang 50125
}

\begin{abstract}
Intisari
Rancang bangun viskosimeter metode bola jatuh berbasis mikrokontroler Atmega16 telah berhasil dilakukan. Viskosimeter berbasis mikrokontroler diujicoba untuk menentukan viskositas gliserin dan membandingkan dengan pengukuran menggunakan viskosimeter konvensional. Hasil percobaan dengan menggunakan viskosimeter berbasis mikrokontroler diperoleh viskositas gliserin dalam rentang $(1,5534-1,5589) \mathrm{N} . \mathrm{s} / \mathrm{m}^{2}$. Viskositas gliserin yang diukur menggunakan viskosimeter konvensional besarnya dalam rentang $(1,4749-1,8703) \mathrm{N} . \mathrm{s} / \mathrm{m}^{2}$. Nilai viskositas gliserin yang didapatkan dengan menggunakan viskosimeter berbasis mikrokontroler memiliki rentang yang sangat kecil dibanding dengan menggunakan viskosimeter konvensional. Hasil pengujian menunjukkan bahwa viskosimeter berbasis mikrokontroler dapat digunakan untuk menentukan viskositas zat cair yang transparan/jernih.
\end{abstract}

KATA KUNCI: viskosimeter, mikrokontroler, Atmega16, fluida

\section{PENDAHULUAN}

Viskositas merupakan sifat fisik yang penting pada fluida. Viskositas fluida memiliki peranan yang penting pada aliran fluida dalam pipa atau media berpori. Selain itu, viskositas fluida juga penting dalam pelumasan mesin, keadaan optimum pelumasan logam dapat dicapai jika permukaan logam yang bersentuhan dilapisi secara sempurna oleh minyak pelumas [1]. Kemampuan pelumas mesin untuk melumasi seluruh permukaan logam terkait erat dengan viskositas pelumas tersebut. Pengukuran viskositas lebih banyak dilakukan pada zat cair dibanding zat gas. Viskositas fluida dapat ditentukan dengan metode yang berbeda, diantaranya yaitu bola jatuh (falling ball), bola bergulir (rolling ball), pipa kapiler, rotasi silinder konsentris (Couette), rotasi kerucut plat, pelat paralel dan Ford-cup [2]. Pengukuran viskositas fluida yang sederhana dan dapat dilakukan di laboratorium skala universitas pada prinsipnya menggunakan viskosimeter metode bola jatuh.

Pada prinsipnya, pengukuran viskositas fluida metode bola jatuh ialah dengan cara mengukur kecepatan bola pejal jatuh di dalam cairan uji. Viskositas fluida ditentukan dengan memasukkan cairan yang akan diukur kekentalannya ke dalam suatu tabung viskosimeter (tabung gelas panjang berskala). Tabung viskosimeter tersebut diberi dua batas dengan jarak (d) tertentu, selanjutnya diukur waktu yang diperlukan bola pejal untuk menempuh dua batas tersebut [3, 4]. Berdasarkan data yang diperoleh dapat ditentukan viskositas

*E-MAIL: didik_phys@yahoo.co.id cairan dengan menggunakan persamaan Poiseuille’s [4].

$$
\eta=\frac{2}{9} \frac{g r^{2}\left(\rho_{B}-\rho_{F}\right)}{v_{\text {maks }}}
$$

dengan $\eta$, S, t, g, r, $\rho_{B}$, dan $\rho_{F}$ secara berurutan adalah viskositas, jarak tempuh bola, waktu tempuh bola, percepatan gravitasi, massa jenis bola, dan massa jenis fluida.

Viskositas fluida dari percobaan diperoleh dari hubungan fungsional antara variabel bebas (jarak) dan variabel terikat (waktu) dengan analisis regresi linear [3]. Namun, untuk menentukan viskositas fluida dengan metode bola jatuh terlebih dahulu diketahui data jari-jari bola, massa jenis bola, massa jenis fluida dan percepatan gravitasi. Pada kenyataannya ada kelemahan utama dalam viskosimeter metode bola jatuh diantaranya adalah kesalahan dalam pengamatan gerak bola dan kesulitan saat menentukan tepatnya waktu yang ditempuh bola dalam fluida dengan jarak (d) [5].

Pengembangan cara pengukuran viskosimeter metode bola jatuh telah dilakukan oleh beberapa peneliti untuk mengurangi kesalahan dan kelemahannnya. Budianto [3] dengan menggunakan regresi linear untuk menentukan viskositas zat cair berdasarkan data yang diperoleh. Mujiman [1] melakukan simulasi pengukuran viskositas minyak pelumas dengan menggunakan mikrokontroler AT89S51. Viskosimeter metode bola jatuh dengan memanfaatkan sensor koil sebagai detektor pencatat waktu telah dilakukan oleh Suciati dan Surtono [5].

Pengukuran viskositas fluida metode bola jatuh yang sudah dilakukan oleh Mujiman [1], Budianto [3], Suciati dan Sartono [5] menggunakan dua batas pada tabung viskosimeter untuk mencari kecepatan bola. Penggunaan dua pembatas untuk jarak tempuh bola jatuh dalam fluida belum dapat dipastikan bola bergerak lurus beraturan atau bola berg- 


\begin{tabular}{|c|c|c|c|}
\hline $\begin{array}{c}\text { Pemberi } \\
\text { Sinyal/Input }\end{array}$ & $\begin{array}{c}\text { Pengendali/ } \\
\text { Kontrol }\end{array}$ & $\begin{array}{c}\text { Pemberi } \\
\text { Informasi/output }\end{array}$ \\
\hline $\begin{array}{r}\text { Sensor } \\
\text { fotodioda }\end{array}$ & $\begin{array}{r}\text { Mikrokontroler } \\
\text { ATmegal6 }\end{array}$ & $\begin{array}{c}\text { LCD (Liquid } \\
\text { crystal display) }\end{array}$ \\
\hline
\end{tabular}

Gambar 1: Diagram blok perangkat keras

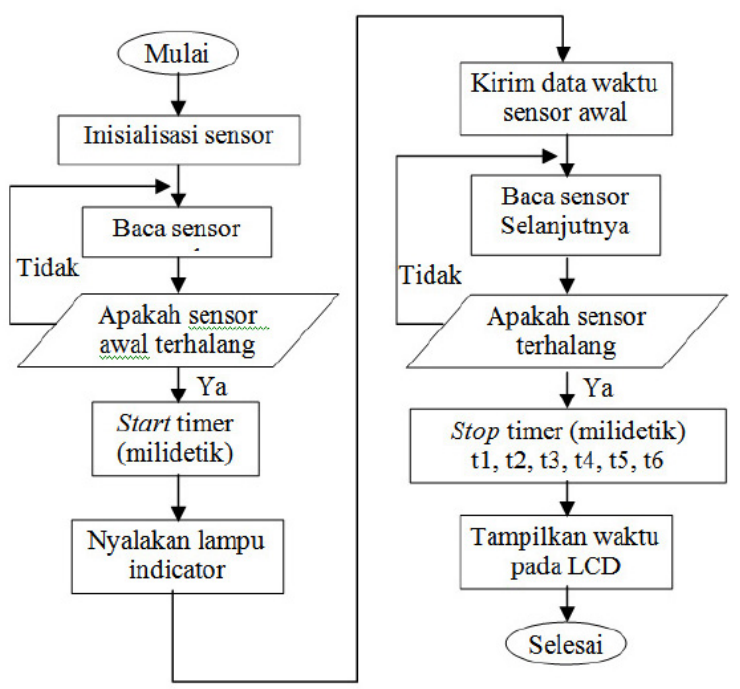

Gambar 2: Diagram alir perancangan perangkat lunak pada Mikrokontroler Atmega16

erak lurus berubah beraturan. Hal tersebut menyebabkan ketidaktentuan dalam hasil pengukuran viskositas zat cair tersebut. Beberapa syarat yang harus diperhatikan dalam menentukan viskositas fluida dengan metode bola jatuh. Diantaranya adalah ruang atau tempat bergeraknya fluida tak terbatas, tidak terjadi aliran turbulensi di dalam fluida, dan kecepatan terminalnya tidak besar. Pada penelitian ini dilakukan rancang bangun viskosimeter metode bola jatuh dengan memanfaatkan teknologi mikrokotroler Atmega16 yang bertujuan meminimalisir kesalahan dalam pencatatan waktu. Alat viskosimeter yang dirancang bangun menggunakan tujuh sensor sebagai batas jarak untuk mengukur kecepatan bola. Viskosimeter berbasis mikrokontroler dapat digunakan untuk menentukan gerak bola dipercepat atau bergerak dengan kecepatan konstan.

\section{METODE}

Metodologi pada penelitian ini meliputi tahap perancangan dan pembuatan perangkat keras, serta perancangan perangkat lunak menggunakan bahasa assembly (software) pada mikrokontroler Atmega16. Selanjutnya, viskosimeter berbasis mikrokontroler diujicoba untuk menentukan viskositas fluida (digunakan gliserin). Diagram blok perancangan dan pembuatan perangkat keras ditunjukkan pada Gambar 1. Sinyal pemberi input berupa tujuh buah sensor fotodioda yang digunakan untuk mendeteksi waktu tempuh bola jatuh
TABEL I: Hasil pengujian sensor

\begin{tabular}{lcc}
\hline \hline Nama & Kondisi & Kondisi \\
Sensor & $\begin{array}{c}\text { Terhalang } \\
\text { Tidak terhalang }\end{array}$ \\
\hline Sensor 1 & 4,49 volt & 0,25 volt \\
Sensor 2 & 4,93 volt & 1,34 volt \\
Sensor 3 & 4,92 volt & 1,36 volt \\
Sensor 4 & 4,49 volt & 1,31 volt \\
Sensor 5 & 4,93 volt & 0,24 volt \\
Sensor 6 & 4,93 volt & 0,41 volt \\
Sensor 7 & 4,93 volt & 0,05 volt \\
\hline \hline
\end{tabular}

dalam fluida. Kemudian sinyal input diproses pada rangkaian mikrokontroler untuk selanjutnya dikeluarkan dalam bentuk tampilan dalam LCD (Liquid Crystal Display).

Perancangan perangkat lunak sangat diperlukan oleh programmer dalam mempermudah menentukan langkah-langkah atau alur dari program. Perancangan perangkat lunak dimulai dengan membuat diagram alir untuk mempermudah langkahlangkah pemprograman. Diagram alir juga difungsikan agar program sesuai dan sinkron dengan perangkat keras, sehingga sesuai dengan yang direncanakan. Diagram alir perancangan perangkat lunak ditunjukkan pada Gambar 2.

Setelah perancangan keseluruhan sistem pada viskosimeter berbasis mikrokontroler selesai dirakit, maka dilakukan pengujian. Pengujian alat dimaksudkan untuk mendapatkan evaluasi terhadap alat yang sudah dirancang bangun, agar diperoleh kinerja yang lebih baik. Pengujian dilakukan pada sistem sensor, sistem minimum mikrokontroler dan pengujian viskositas berbasis mikrokontroler. Viskosimeter berbasis mikrokontroler digunakan untuk menentukan viskositas gliserin dan dibandingkan dengan viskosimeter konvensional. Data yang diperoleh adalah waktu tempuh bola yang bergerak antara sensor dalam gliserin. Berdasarkan persamaan Poiseuille's, viskositas cairan yang ditentukan dengan metode bola jatuh didasarkan pada kecepatan terminal/gerak lurus beraturan. Kecepatan gerak bola dalam zat cair digunakan sebagai indikasi bahwa bola bergerak lurus beraturan. Setelah terpenuhi hal tersebut, selanjutnya data hasil pengukuran waktu dianalisis untuk menentukan kecepatan dan selanjutnya untuk mendapatkan nilai viskositas gliserin.

\section{HASIL DAN PEMBAHASAN}

Pengujian pada sistem viskosimeter dilakukan pengecekan operasional terhadap fungsi bagian-bagian sistem. Hasil pengecekan sistem sensor ditunjukkan pada Tabel I. Hasil pengujian menunjukkan bahwa sistem sensor berfungsi dengan baik. Sistem sensor berlogika 1 saat sensor terhalang, dan memberi logika 0 saat sensor tidak terhalang. Saat bola jatuh melewati sensor (sensor terhalang) maka keluaran sensor berlogika 1 yang memberikan input pada sistem mikrokontroler. Hasil tersebut menunjukkan bahwa sistem sensor dapat digunakan dalam viskosimeter berbasis mikrokontroler untuk mendeteksi waktu tempuh bola jatuh di dalam fluida.

Sistem mikrokontroler merupakan sistem pengendali semua rangkaian yang ada pada viskosimeter. Proses pen- 


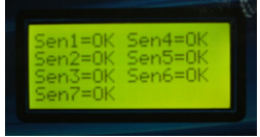

Gambar 3: Hasil output dari input cek sensor yang ditampilkan pada LCD

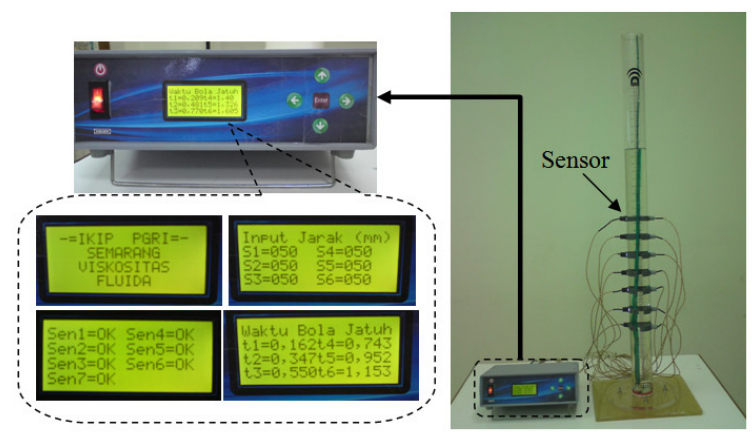

Gambar 4: Viskosimeter bola jatuh berbasis mikrokontroler Atmega 16

gujian sistem minimum mikrokontroler dilakukan dengan menghubungkan sistem sensor sebagai input dan LCD sebagai output. Sebuah program sederhana untuk mengecek kondisi sensor yang hasilnya ditampilkan di LCD diisikan kedalam mikrokontroler. Hasil pengujian sistem mikrokontroler ditunjukkan pada Gambar 3. Berdasarkan hasil pengujian menunjukkan bahwa input-output berfungsi dengan baik. Hal ini berarti sistem mikrokontroler dapat digunakan dalam alat praktikum viskositas fluida.

Hasil perancangan viskosimeter bola jatuh berbasis mikrokontroler Atmega 16 ditunjukkan pada Gambar 4. Prinsip kerja dari viskosimeter intinya pada tabung viskosimeter, sistem sensor dan sistem mikrokontroler. Sistem sensor digunakan untuk memberi masukan pada mikrokontroler, dimana digunakan 7 sensor fotodioda. Setelah jarak diatur dan sensor pada kondisi siap digunakan, maka bola dijatuhkan dalam tabung viskosimeter yang berisi gliserin. Ketika bola dijatuhkan dalam fluida, maka sensor pertama mengaktifkan waktu pada sistem mikrokontroler. Sensor-sensor selanjutnya mendeteksi waktu yang diperlukan bola bergerak dari sensor satu ke sensor yang lain. Sistem mikrokontroler akan menampilkan waktu yang diperlukan bola untuk bergerak dari sensor satu ke sensor yang lain (jarak antar sensor $5 \mathrm{~cm}$ dan $7 \mathrm{~cm}$ ) ke LCD. Waktu yang diperoleh adalah waktu dari sen-

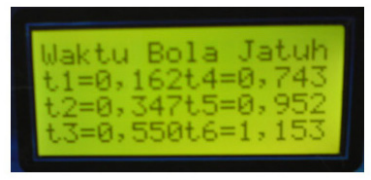

(a)

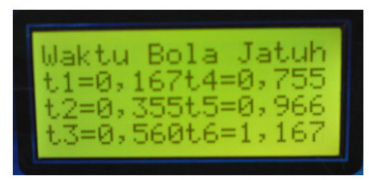

(b)
Gambar 5: Hasil output waktu bola jatuh yang ditampilkan pada LCD (a) pengukuran 1 (b) pengukuran 2
TABEL II: Data hasil pengukuran menggunakan viskosimeter berbasis mikrokontroler

\begin{tabular}{ccccc}
\hline \hline & \multicolumn{2}{c}{ Pengukuran 1 } & \multicolumn{2}{c}{ Pengukuran 2 } \\
& Jarak $(\mathrm{cm})$ & Waktu (s) & Jarak $(\mathrm{cm})$ & Waktu (s) \\
\hline Sensor 1 - 2 & 5 & 0,162 & 7 & 0,209 \\
Sensor 1 - 3 & 10 & 0,347 & 14 & 0,481 \\
Sensor 1 - 4 & 15 & 0,550 & 21 & 0,770 \\
Sensor 1 - 5 & 20 & 0,743 & 28 & 1,040 \\
Sensor 1 - 6 & 25 & 0,952 & 35 & 1,326 \\
Sensor 1 - 7 & 30 & 1,153 & 42 & 1,605 \\
\hline \hline
\end{tabular}

TABEL III: Data hasil pengukuran menggunakan viskosimeter konvensional

\begin{tabular}{cccc}
\hline \hline \multicolumn{2}{c}{ Pengukuran 1 } & \multicolumn{2}{c}{ Pengukuran 2 } \\
Jarak (cm) & Waktu (s) & Jarak (cm) & Waktu (s) \\
\hline 5 & 0,27 & 7 & 0,50 \\
10 & 0,35 & 14 & 0,71 \\
15 & 0,70 & 21 & 0,99 \\
20 & 0,93 & 28 & 1,22 \\
25 & 1,05 & 35 & 1,45 \\
30 & 1,24 & 42 & 1,63 \\
\hline \hline
\end{tabular}

sor 1 ke sensor 2 , sensor 1 ke sensor 3 , sensor 1 ke sensor 4 , sensor 1 ke sensor 5 , sensor 1 ke sensor 6 dan sensor 1 ke sensor 7. Hasil output dari pengukuran waktu tempuh ditunjukkan pada Gambar 5. Kecepatan bola jatuh dalam gliserin merupakan kunci utama untuk menentukan besarnya viskositas gliserin (seperti ditunjukkan pada Pers. 1.

Pengukuran viskositas fluida melalui kegiatan praktikum dengan menggunakan alat viskosimeter berbasis mikrokontroler telah dilakukan. Pengukuran viskositas fluida dengan menggunakan viskosimeter berbasis mikrokontroler dilakukan dengan menggunakan metode bola jatuh dengan suhu ruangan praktikum $22^{\circ} \mathrm{C}$. Pengujian alat dilakukan pada sampel gliserin dengan menggunakan bola berdiameter $(16,50$ $\pm 0,005) \mathrm{mm}$ dengan massa $(5,42 \pm 0,005)$ gram. Pada pengukuran viskositas gliserin, data hasil pengukuran berupa hubungan antara jarak sensor dan waktu bola bergerak dari sensor satu ke sensor (bola jatuh melewati sensor 1 sampai 7). Data diambil menggunakan alat viskosimeter berbasis mikrokontroler dan secara konvensional (manual). Hal ini dilakukan untuk membandingkan keakuratan pengukuran waktu saat bola jatuh. Hasil pengukuran waktu dengan variasi jarak antar sensor $5 \mathrm{~cm}$ menggunakan viskosimeter berbasis mikrokontroler ditunjukkan pada Tabel II dan secara manual ditunjukkan pada Tabel III.

Berdasarkan hasil pengukuran menggunakan viskosimeter bola jatuh berbasis mikrokontroler diperoleh waktu pada 6 variasi jarak dengan sekali pengukuran. Hasil yang konsisten juga didapatkan ketika percobaan diulang kembali dengan jarak sensor yang sama. Sedangkan untuk mendapatkan waktu bola jatuh dengan 6 variasi jarak secara manual dilakukan pengukuran masing-masing untuk setiap jarak secara berulang. Pengukuran secara berulang dilakukan untuk mendapatkan hasil waktu yang konsisten dengan percobaan 1 dan 2. Hasil yang diperoleh dengan pengukuran waktu 


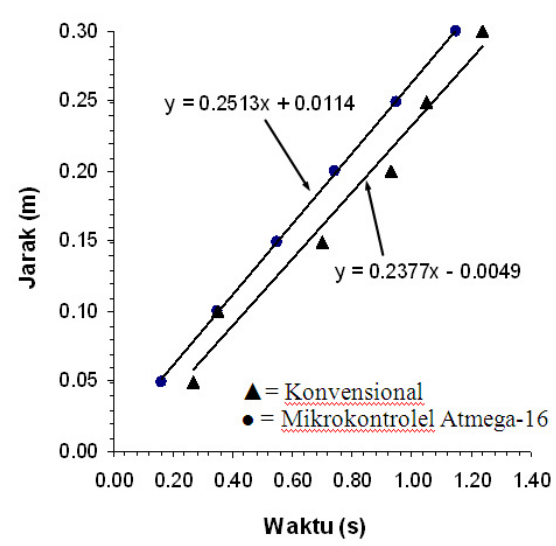

Gambar 6: Grafik hubungan jarak dan waktu bola jatuh dalam gliserin dengan variasi jarak $5 \mathrm{~cm}$.

menggunakan stopwatch (manual) terdapat perbedaan sebesar $(0,1-0,2)$ sekon dengan hasil pengukuran otomatis. Perbedaan ini mungkin dikarenakan kesalahan dalam pengamatan gerak bola akibat tidak lurusnya pandangan. Selain itu disebabkan karena kelelahan atau kerusakan mata pengamat dan juga tidak serempaknya pengamatan bola dan pengamatan pencatatan waktu. Hal itu sesuai dengan kelemahan utama pengukuran viskositas metode bola jatuh secara manual [5].

Alat viskosimeter berbasis mikrokontroler yang digunakan mampu mengukur waktu untuk jarak yang lebih pendek dibandingkan secara manual (menggunakan stopwatch). Selain itu waktu lebih konsisten dan ralat lebih kecil dibanding dengan pengukuran secara manual. Hasil ini sama dengan penelitian yang dilakukan Mujiman [1] yang menggunakan fototransistor dalam mengukur waktu bola jatuh dalam tabung viskosimeter. Hasil pengukuran waktu sangat berpengaruh terhadap keakuratan pengukuran viskositas gliserin yang dilakukan dengan metode viskosimeter bola jatuh.

Data hasil pengukuran viskositas gliserin waku bola jatuh dengan menggunakan viskosimeter bola jatuh berbasis mikrokontroler dan viskosimeter konvensional ditunjukkan pada grafik seperti dalam Gambar 6 dan Gambar 7. Hasil analisis dari semua data pengukuran menunjukkan hubungan linier antara jarak dan waktu bola jatuh. Berdasarkan grafik diperoleh besarnya kecepatan bola jatuh yang selanjutnya digunakan untuk menentukan viskositas gliserin (lihat Pers.1).

Gambar 6 menunjukkan besarnya kecepatan bola jatuh di dalam gliserin yang diperoleh dari hubungan data pengukuran (dengan jarak $5 \mathrm{~cm}$ ) menggunakan viskosimeter berbasis mikrokontroler dan viskosimeter konvensional. Kecepatan bola jatuh dalam gliserin merupakan fungsi linier dari jarak dengan waktu bola jatuh. Besarnya kecepatan bola jatuh antara pengukuran pertama dan kedua tidak begitu signifikan. Pada pengukuran menggunakan viskosimeter berbasis mikro kontroler, besarnya kecepatan bola jatuh dalam gliserin adalah $(0,2512 \pm 0,000004) \mathrm{m} / \mathrm{s}$ dan untuk pengukuran menggunakan viskosimeter konvensional $(0,2377 \pm 0,0003) \mathrm{m} / \mathrm{s}$. Berdasarkan hasil kecepatan, pengukuran viskositas gliserin

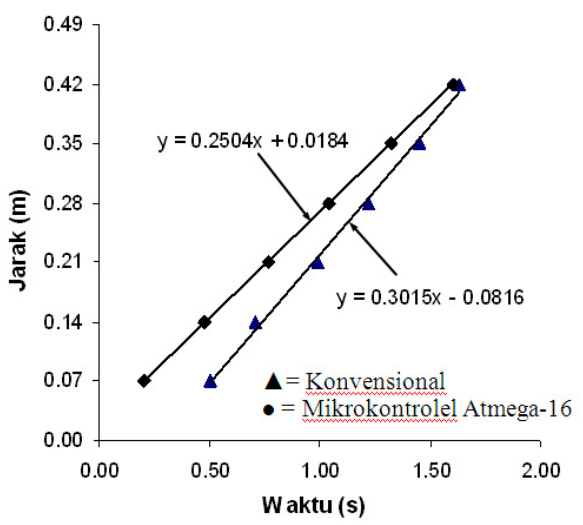

Gambar 7: Grafik hubungan jarak dan waktu bola jatuh dalam gliserin dengan variasi jarak $7 \mathrm{~cm}$.

dengan menggunakan viskosimeter berbasis mikrokontroler diperoleh sebesar $(1,5589 \pm 0,000006)$ N.s $/ \mathrm{m}^{2}$. Sedangkan pada pengukuran dengan menggunakan viskosimeter konvensional didapatkan besarnya viskositas gliserin $(1,4749 \pm$ 0,00046) N.s/m²

Pengukuran kecepatan bola jatuh dalam gliserin menggunakan viskosimenter berbasis mikrokontroler dan viskosimeter konvensional dengan variasi jarak $7 \mathrm{~cm}$ ditunjukkan pada Gambar 7. Berdasarkan analisis grafik didapatkan kecepatan bola jatuh yang diperoleh dengan menggunakan viskosimeter berbasis mikrokontroler adalah $(0,2504 \pm 0,000001) \mathrm{m} / \mathrm{s}$. Kecepatan bola jatuh dalam gliserin yang diukur menggunakan viskosimeter konvensional didapatkan $(0,3015 \pm 0,00007)$ $\mathrm{m} / \mathrm{s}$. Berdasarkan hasil kecepatan bola jatuh dalam fluida, besarnya viskositas gliserin untuk pengukuran menggunakan viskosimeter berbasis mikrokontroler $(1,5534 \pm 0,000002)$ $\mathrm{N} . \mathrm{s} / \mathrm{m}^{2}$, sedangkan menggunakan viskosimeter konvensional adalah $(1,8703 \pm 0,0001) \mathrm{N} . \mathrm{s} / \mathrm{m}^{2}$. Hasil viskositas gliserin yang didapatkan dari pengukuran menggunakan viskosimeter berbasis mikrokontroler lebih konsisten jika dibandingkan dengan menggunakan viskosimeter berbasis mikrokontroler seperti ditunjukkan pada Tabel IV.

Hasil pengukuran viskositas gliserin yang dilakukan menggunakan viskosimeter berbasis mikrokontroler hampir sama dengan viskositas fluida yang diukur pada suhu $20^{\circ} \mathrm{C}$ pada tekanan 1 atm yang besarnya $1,49 \mathrm{Ns} / \mathrm{m}^{2}$ [6]. Namun berbeda dengan hasil pengukuran yang dilakukan menggunakan viskosimeter konvensional, dimana dengan jarak $5 \mathrm{~cm}$ dan $7 \mathrm{~cm}$ didapatkan nilai viskositas gliserin yang berbeda (dapat dilihat pada Tabel IV). Perbedaan hasil viskositas gliserin yang dilakukan menggunakan viskosimeter konvensional dimungkinkan adanya ketidak-akuratan dalam pengukuran waktu ketika bola jatuh dalam gliserin. Hal ini menyebabkan kurang liniernya antara perubahan jarak dengan waktu tempuh bola. Kecepatan bola jatuh dalam gliserin sangat berpengaruh pada perhitungan viskositas gliserin. Pada persamaan 1 jelas terlihat bahwa besarnya viskositas fluida yang diukur dengan menggunakan viskosimeter metode bola sangat dipengaruhi oleh kecepatan bola jatuh. Kecepatan bola jatuh yang diukur dengan menggunakan viskosimeter berbasis mikrokontroler 
TABEL IV: Perbandingan pengukuran viskositas gliserin menggunakan viskosimeter berbasis mikrokontroler dan konvensional

\begin{tabular}{lcc}
\hline \hline Pengukuran & \multicolumn{2}{c}{ Viskositas gliserin (N.s/m $\left.{ }^{2}\right)$} \\
& Konvensional & Mikrokontroler \\
\hline Pengukuran 1 & $1,4749 \pm 0,00046$ & $1,5589 \pm 0,000006$ \\
Pengukuran 2 & $1,4620 \pm 0,00048$ & $1,5441 \pm 0,000004$ \\
\hline \hline
\end{tabular}

sangat akurat. Pengukuran waktu bola jatuh digunakan pencacah waktu pada sistem mikrokontroler. Hal ini memudahkan dalam pengukuran kecepatan bola jatuh dan juga akan menyebabkan keakuratan dalam pengukuran viskositas fluida yang dilakukan dengan alat ini.

Hasil ujicoba alat viskosimeter berbasis mikrokontroler menunjukkan bahwa alat viskosimeter berbasis mikrokontroler dapat digunakan untuk menentukan viskositas gliserin. Viskosimeter berbasis mikrokontroler terbukti lebih akurat dalam pengukuran viskositas gliserin dibanding dengan pengukuran yang dilakukan menggunakan viskosimeter konvensional. Namun alat viskosimeter berbasis mikrokontroler dengan menggunakan sensor fotodioda/cahaya belum dapat digunakan untuk mengukur viskositas zat cair yang berwarna gelap. Berdasarkan hasil yang diperoleh pada rancang bangun dan ujicoba, alat viskosimeter berbasis mikrokontroler ini dapat digunakan untuk praktikum viskositas fluida dalam mata kuliah praktikum Fisika Dasar 1. Selain itu juga diharapkan dapat digunakan untuk pengembangan praktikum tentang viskositas dan juga dapat membantu dalam menjelaskan konsep fluida.

\section{SIMPULAN}

Telah berhasil dilakukan rancang bangun viskosimeter bebasis mikrokontroler Atmega 16. Viskosimeter berbasis mikrokontroler telah digunakan untuk mengukur viskositas gliserin. Hasil pengukuran waktu bola jatuh menggunakan viskosimeter berbasis mikrokontroler lebih akurat jika dibandingkan dengan pengukuran menggunakan viskosimeter konvensional. Viskositas gliserin yang diukur dengan viskosimeter berbasis mikrokontroler besarnya dalam rentang $(1,5534-1,5589) \mathrm{N} . \mathrm{s} / \mathrm{m}^{2}$. Viskositas gliserin yang diukur secara manual besarnya dalam rentang $(1,4749$ - 1,8703) N.s $/ \mathrm{m}^{2}$. Viskosimeter berbasis mikrokontroler dapat digunakan sebagai pengganti alat praktikum viskositas fluida sederhana. Pengembangan praktikum viskositas fluida dapat menggunakan alat viskosimeter berbasis mikrokontroler. Kedepannya dapat dilakukan pengembangan alat viskosimeter untuk mengukur secara otomatis kecepatan bola yang bergerak dalam fluida. Alat viskosimeter berbasis mikrokontroler juga dapat dikembangkan untuk menjelaskan konsep fluida dalam perkuliahan melalui kegiatan praktikum.

\section{Ucapan Terima Kasih}

Penulis mengucapkan terimakasih kepada LPPM IKIP PGRI Semarang untuk financial support dalam penelitian ini. Kami juga menyampaikan terimakasih kami kepada Program Studi Pendidikan Fisika, FPMIPA, IKIP PGRI Semarang untuk fasilitas laboratorium.
[1] Mujiman, TELKOMNIKA, 6, 1, 49 (2008).

[2] K. Walters and W. Jones, Measurement of Viscosity (Instrumentation Reference Book. Editor B. E. Noltingk. Oxford, ButterwothHeineman, 1996).

[3] A. Budianto, Metode Penentuan Koefisien Kekentalan Zat Cair dengan Menggunakan Regresi Linear Hukum Stokes, Seminar Nasional IV SDM Teknologi Nuklir, 157-166, Yogyakarta: Sekolah Tinggi Teknologi Nuklir, 2008.

[4] A. W. Sears and M. W. Zemansky, University Physics (Terjema- han Soerdajana dan Amir Achmad. Jakarta, Bina Cipta, 1991).

[5] S. W. Suciati dan A. Surtono, Pemanfaatan Sensor Koil Sebagai Detektor Pencatat Waktu pada Viscosimeter Metode Bola Jatuh Berbasis Komputer, Seminar Hasil Penelitian dan Pengabdian Kepada Masyarakat. 143-149. Lampung, Universitas Lampung, 2009.

[6] F. M. White, Fluid Mechanics (Newyork, McGraw-Hill, 1986). 